\title{
PAH Concentrations Inside a Wood Processing Plant and the Indoor Effects of Outdoor Industrial Emissions
}

\author{
Patrycja Rogula-Kopiec ${ }^{1}$, Wioletta Rogula-Kozlowska', \\ Barbara Kozielska ${ }^{2 *}$, Izabela Sówka ${ }^{3}$ \\ 'Institute of Environmental Engineering, Polish Academy of Sciences, \\ M. Skłodowska-Curie 34, 41-819 Zabrze, Poland \\ ${ }^{2}$ Department of Air Protection, Silesian University of Technology, \\ Konarskiego 22B, 44-100 Gliwice, Poland \\ ${ }^{3}$ Environmental Protection Engineering Institute, Wroclaw University of Technology, \\ Wybrzeże Wyspiańskiego 27, 50-370 Wroclaw, Poland
}

Received: 27 January 2015

Accepted: 18 February 2015

\begin{abstract}
Our study was aimed at assessing the effects of indoor and outdoor emission sources on indoor and outdoor concentrations of ambient particulate matter (PM) and PM-bound polycyclic aromatic hydrocarbons (PAHs) in a small sawmill in Silesia, Poland. The concentrations of total suspended particles (TSP), of their respirable fraction $\left(\mathrm{PM}_{4}\right)$, and of $16 \mathrm{PM}_{4}$ - and TSP-bound PAHs were measured. The indoor PM emission sources (i.e. the saw and other tools for wood processing) did not cause a significant hazard to the sawmill workers. Nonetheless, the concentrations of the 16 PAH mixtures within the sawmill were high, especially indoors. Such high indoor PM-bound PAH concentrations were due to sawdust-adsorbing PAHs coming from industrial PAH sources beyond the sawmill (a cokery).
\end{abstract}

Keywords: sawmill, particulate matter, respirable dust, health hazard, persistent organic pollutants

\section{Introduction}

Until the late 1990s, the basis for the Silesian economy could have been very aptly identified with heavy industry and hard coal excavation $[1,2]$. Later, after two decades of Polish economic evolution, these sectors lost their importance in favor of other, less heavy industries, and now small and medium-sized companies from the sectors of commerce, craft, service, construction, transport, and accommodation, etc. are $99 \%$ of all the business entities in Silesia Province [3]. This change in the structure of employment thoroughly rearranged the Silesian occupational health hazard inventory.

*e-mail: Barbara.Kozielska@polsl.pl
Usually, the air inside factory production buildings is polluted - with what depends on the factory profile [4-8]. The hazard to the workers depends on the type and concentration of the pollutants [9-11]. The concentrations of some production-related substances at some worksites, e.g. assembly lines, are routinely controlled according to the law [12]. However, in some circumstances foreign pollutants coming from outdoor sources are more hazardous to indoor workers than the production-related substances released inside buildings. Outdoor emissions from the factory neighborhood can then degrade the indoor air more than emissions from production.

The goal of the study was to apportion between outdoor and indoor sources the concentrations of total suspended 
particles (TSP), its respirable sub-fraction of the particles with aerodynamic diameter not greater than $4 \mu \mathrm{m}\left(\mathrm{PM}_{4}\right)$, and of some polycyclic aromatic hydrocarbons (PAHs), adsorbed on these particles, in a sawmill. The sawmill was equipped with several wood-processing lines situated in relatively tightly closed halls. It was located in Biskupice, in a heavily polluted quarter of Zabrze, a city in the Upper Silesia Agglomeration. There were some industrial utilities nearby, including a large cokery.

\section{Material and Methods}

We selected six sampling points within the sawmill area (Fig. 1). Two points, $\mathrm{P} 1$ and P2, were located in building $\mathrm{B} 1, \mathrm{P} 1$ at the saw and $\mathrm{P} 2$ at the other end of the building, practically beyond the effect of sawing. Point P3 was located in open shed B2, where wood-sawing occurs for 1 to 3 hours a day. Point P4 was located at sawmill entrance gate G, practically on the factory area border. Points P5 and P6 were located in the main production building B3, P5 at the main sawmill line, and P6 at the control room far from the production utilities.

Two SKC aspirators (Blandford, Dorset, U.K.) were located at each sampling point, at about $1.6 \mathrm{~m}$ above ground level - one adjusted to sample $\mathrm{PM}_{4}$, the second to sample TSP. Within 05.03.2014-15.04.2014, at each point, four eight-hour samples of both $\mathrm{PM}_{4}$ and TSP were taken according to the Polish Norms [13, 14], which defines the method for making measurements at worksites with the use of an SKC aspirator.

The quartz fiber filters (QMA, ø25 mm, CAT No. 1851025; Whatman, GE Healthcare Bio-Sciences Corp.; Piscataway, NJ, USA) were mounted on and taken away from the aspirators in a laminar airflow cabinet). Prior to sampling, the quartz fiber filters were baked at $600^{\circ} \mathrm{C}$ for at least $6 \mathrm{~h}$ to remove any traces of organics. The dust-loaded substrates, right after their weighing, were put into Petri dishes wrapped light-tightly in aluminum foil and stored in a freezer $\left(-18^{\circ} \mathrm{C}\right)$ until analysis.

The masses of the samples were determined by weighing the substrates before and after exposure (MYA 5.3Y.F microbalance; RADWAG, Radom, Poland; resolution of $1 \mu \mathrm{g}$ ). They were conditioned in the weighing room (air humidity of $45 \pm 5 \%$, air temperature $20 \pm 2^{\circ} \mathrm{C}$ ) for 48 hours before each weighing.

To determine the PM-bound PAH concentrations, all four samples of $\mathrm{PM}_{4}$ or TSP from a sampling point were put together to make one cumulative sample of $\mathrm{PM}_{4}$ or TSP, respectively. These cumulative samples were extracted and the extracts were chromatographically examined for the presence of naphthalene (Na), acenaphthylene (Acnl), acenaphtene (Acn), fluorene (Flu), phenanthrene (Phen), anthracene (An), fluoranthene (Flt), pyrene (Pyr), benzo[a]anthracene $(\mathrm{BaA})$, chrysene $(\mathrm{Ch})$, benzo[b]fluoranthene $(\mathrm{BbF})$, benzo[k]fluoranthene $(\mathrm{BkF})$, benzo[a]pyrene (BaP), indeno[1,2,3-cd]pyrene (IP), dibenzo[ah] anthracene (DahA), and benzo[ghi]perylene (BghiP) (Fig. 1).
The extraction, the chromatography technique, and validation parameters are described in $[15,16]$.

Four coefficients were computed expressing the hazards from the mixture of the 16 PAHs ( $\mathrm{PAH})$ : carcinogenic equivalent (CEQ), mutagenic equivalent (MEQ), TCDD-toxic equivalent (TEQ), and the share of the carcinogenic PAHs $\left(\sum \mathrm{PAH}_{\text {carc }}\right)$ in $\left(\sum \mathrm{PAH}\right)$. The coefficients and the methods for their computing are described in [15].

\section{Results and Discussion}

According to the Ordinance of the Minister of Labor and Social Policy, the sawdust contained in the inhalable fraction of ambient dust is the only air contaminant whose ambient concentrations is obligatorily measured at worksites in Polish sawmills. In the meaning of the Ordinance, the inhalable dust fraction is the whole of TSP [12]. However, the hazard from TSP to workers comes mainly from respirable dust, $\mathrm{PM}_{4}$. In the case of the investigated sawmill utilities, the hazard was not great, the $\mathrm{PM}_{4}$ and TSP concentrations (both 8-h and averaged) were below the permissible limits at all measuring points (Fig. 1).

The highest concentrations of $\mathrm{PM}_{4}$ occurred at $\mathrm{P} 1, \mathrm{P} 2$, $\mathrm{P} 4$, and $\mathrm{P} 6$, in average $45,48,30$, and $23 \mu \mathrm{g} \cdot \mathrm{m}^{-3}$, respectively; except for P4, all in the production halls (Fig. 1). At P3 and P5, the 8-h $\mathrm{PM}_{4}$ concentrations varied between 8 and $18 \mu \mathrm{g} \cdot \mathrm{m}^{-3}$ and the average concentrations were 16 and $13 \mu \mathrm{g} \cdot \mathrm{m}^{-3}$, respectively.

At $\mathrm{P} 2, \mathrm{P} 5$, and $\mathrm{P} 6$ in the production halls, the average concentrations of TSP were 845, 589, and $601 \mu \mathrm{g} \cdot \mathrm{m}^{-3}$, respectively, and at $\mathrm{P} 5$ at the gate to the sawmill: 555 $\mu \mathrm{g} \cdot \mathrm{m}^{-3}$. At P3, in the open shed, and at P1, at the saw for cutting logs into lumber, they were 149 and $161 \mu \mathrm{g} \cdot \mathrm{m}^{-3}$. At P3 and $\mathrm{P} 1$ the $\mathrm{PM}_{4}$ mass content of TSP was high compared to other points. At P1 it was highest and varied from 11 to $59 \%$, and its four-measurement average was $28 \%$ (Fig. 1). At $\mathrm{P} 3$ the average $\mathrm{PM}_{4}$ content of TSP was $10 \%$, at the rest of the points it was less than $10 \%$.

Compared to the outdoor points, the wood processing itself appeared not to elevate significantly the indoor sawdust concentrations nor the shares of respirable fraction in TSP. The highest concentrations of $\mathrm{PM}_{4}$ were noted at P1, at the main saw, but they were only a little higher than the $\mathrm{PM}_{4}$ concentrations at $\mathrm{P} 4$ at the gate to the sawmill.

Instead, the PAH concentrations in the sawmill were enormously high (Fig. 1). The highest occurred in building $\mathrm{B} 1$ at the saw, at P2, where the TSP-bound $\sum \mathrm{PAH}$ concentration reached $1,425 \mathrm{ng} \cdot \mathrm{m}^{-3}$; the $\mathrm{PM}_{4}$-bound $\sum \mathrm{PAH}$ concentrations at P2 was $329 \mathrm{ng} \cdot \mathrm{m}^{-3}$. Although the TSP-bound $\sum \mathrm{PAH}$ concentrations at $\mathrm{P} 3$ and $\mathrm{P} 6$ were two times lower than at $\mathrm{P} 2$, the $\mathrm{PM}_{4}$-bound $\sum \mathrm{PAH}$ concentrations at these points, 365 and $335 \mathrm{ng} \cdot \mathrm{m}^{-3}$, were similar to this at $\mathrm{P} 2$. At $\mathrm{P} 1$, at the other end of $\mathrm{B} 1$, the $\mathrm{PM}_{4}$ - and TSP-bound $\sum \mathrm{PAH}$ concentrations were lower than at $\mathrm{P} 2$. The differences between $\mathrm{P} 1$ and $\mathrm{P} 2$ in the $\sum \mathrm{PAH}$ concentrations were proportional to the differences in the dust concentrations 

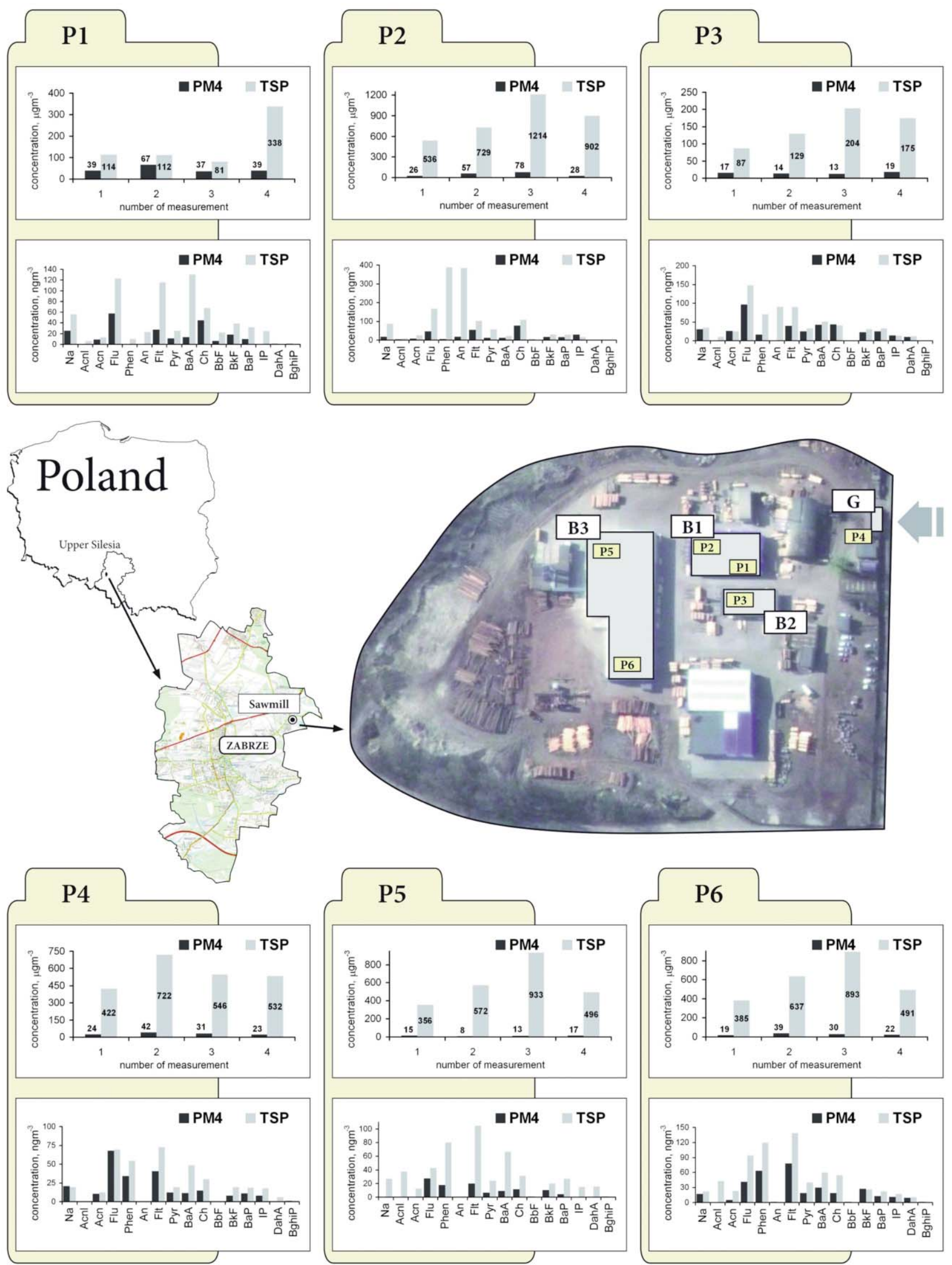

Fig. 1. Location of the sampling points, 8-h concentrations of $\mathrm{PM}_{4}$ and TSP, and the average concentrations of $\mathrm{PM}_{4}$ - and TSP-bound PAHs in the sawmill. 
Table 1. PAH profiles at the six sampling points in the sawmill.

\begin{tabular}{|c|c|c|c|c|c|c|c|c|c|c|c|c|c|c|c|c|}
\hline $\begin{array}{c}\mathrm{PM} \\
\text { fraction, }\end{array}$ & & & & & PAHs ra & nked by & ambient & concen & ations & owing & from le & to rig & & & & \\
\hline $\mathrm{PM}_{4}, \mathrm{P} 1$ & Acnl & Phen & IP & DahA & BghiP & Pyr & Acn & $\mathrm{BaA}$ & $\mathrm{BkF}$ & $\mathrm{BbF}$ & An & $\mathrm{Na}$ & Flt & $\mathrm{BaP}$ & $\mathrm{Ch}$ & Flu \\
\hline TSP, P1 & $\mathrm{BbF}$ & DahA & BghiP & Acnl & IP & $\mathrm{BaA}$ & Acn & $\mathrm{BaP}$ & $\mathrm{BkF}$ & Pyr & $\mathrm{Na}$ & Flt & $\mathrm{Ch}$ & Flu & An & Phen \\
\hline $\mathrm{PM}_{4}, \mathrm{P} 2$ & An & DahA & BghiP & Acnl & $\mathrm{BbF}$ & Acn & Phen & $\mathrm{BaP}$ & IP & Pyr & $\mathrm{BkF}$ & $\mathrm{Na}$ & $\mathrm{Ch}$ & Flt & Flu & $\mathrm{BaA}$ \\
\hline TSP, P2 & DahA & $\mathrm{BbF}$ & Acnl & Phen & Acn & BghiP & $\mathrm{BaA}$ & Pyr & $\mathrm{BaP}$ & $\mathrm{BkF}$ & An & $\mathrm{Na}$ & IP & Flu & Flt & $\mathrm{Ch}$ \\
\hline $\mathrm{PM}_{4}, \mathrm{P} 3$ & Acnl & $\mathrm{BbF}$ & BghiP & DahA & IP & Phen & $\mathrm{BkF}$ & $\mathrm{BaP}$ & Acn & $\mathrm{Na}$ & Pyr & Flt & $\mathrm{BaA}$ & $\mathrm{Ch}$ & An & Flu \\
\hline TSP, P3 & Acnl & An & $\mathrm{BbF}$ & DahA & BghiP & $\mathrm{BkF}$ & IP & Acn & $\mathrm{BaP}$ & $\mathrm{BaA}$ & Pyr & $\mathrm{Ch}$ & $\mathrm{Na}$ & Phen & Flt & Flu \\
\hline $\mathrm{PM}_{4}, \mathrm{P} 4$ & An & $\mathrm{BbF}$ & BghiP & Acnl & DahA & IP & Acn & Pyr & $\mathrm{BkF}$ & $\mathrm{BaP}$ & $\mathrm{Na}$ & $\mathrm{Ch}$ & $\mathrm{BaA}$ & Phen & Flt & Flu \\
\hline TSP, P4 & Acnl & An & $\mathrm{BbF}$ & BghiP & DahA & Acn & IP & $\mathrm{BaP}$ & $\mathrm{Na}$ & Pyr & $\mathrm{BkF}$ & $\mathrm{Ch}$ & $\mathrm{BaA}$ & Phen & Flu & Flt \\
\hline $\mathrm{PM}_{4}, \mathrm{P} 5$ & $\mathrm{Na}$ & Acnl & Acn & An & $\mathrm{BbF}$ & IP & DahA & BghiP & $\mathrm{BaP}$ & Pyr & $\mathrm{BaA}$ & $\mathrm{BkF}$ & $\mathrm{Ch}$ & Phen & Flt & Flu \\
\hline TSP, P5 & Acnl & An & $\mathrm{BbF}$ & BghiP & DahA & $\mathrm{BaP}$ & IP & $\mathrm{Na}$ & Acn & $\mathrm{BkF}$ & Pyr & $\mathrm{Ch}$ & $\mathrm{BaA}$ & Flu & Phen & Flt \\
\hline $\mathrm{PM}_{4}, \mathrm{P} 6$ & An & $\mathrm{BbF}$ & BghiP & Acn & IP & DahA & $\mathrm{BkF}$ & Pyr & $\mathrm{Na}$ & $\mathrm{BaP}$ & $\mathrm{Ch}$ & Acnl & Flu & $\mathrm{BaA}$ & Phen & Flt \\
\hline TSP, P6 & An & $\mathrm{BbF}$ & Acn & BghiP & DahA & IP & $\mathrm{Na}$ & $\mathrm{Ch}$ & Pyr & $\mathrm{BaP}$ & $\mathrm{BkF}$ & $\mathrm{BaA}$ & Flu & Acnl & Phen & Flt \\
\hline
\end{tabular}

between these points. At gate $\mathrm{G}$, beyond the sawmill installations, the $\mathrm{PM}_{4^{-}}$and TSP-bound $\sum \mathrm{PAH}$ concentrations were $240 \mathrm{ng} \cdot \mathrm{m}^{-3}$ and $387 \mathrm{ng} \cdot \mathrm{m}^{-3}$. They were low compared to the concentrations at other points, but still high compared to the concentrations in the region $[17,18]$.

Table 2. PAH diagnostic ratios for the six sampling points in the sawmill.

\begin{tabular}{|c|c|c|c|}
\hline $\begin{array}{l}\text { PM fraction, } \\
\text { location }\end{array}$ & $\mathrm{Flt} /(\mathrm{Flt}+\mathrm{Pyr})$ & $\begin{array}{c}\mathrm{BaA} / \\
(\mathrm{BaA}+\mathrm{Ch})\end{array}$ & BaP/BghiP \\
\hline $\begin{array}{l}\text { Coal/coke } \\
{[20,22-24]}\end{array}$ & 0.53 & 0.5 & $>1.25$ \\
\hline $\begin{array}{l}\text { Coke in Upper } \\
\text { Silesia [8] }\end{array}$ & $\begin{array}{c}0.54 \\
(0.5-0.6)\end{array}$ & $\begin{array}{c}0.47 \\
(0.40-0.51)\end{array}$ & $\begin{array}{c}3.9 \\
(1.37-12.18)\end{array}$ \\
\hline $\begin{array}{l}\text { Wood burning } \\
{[20,22-26]}\end{array}$ & $>0.5$ & 0.86 & $0.9-6.6$ \\
\hline $\mathrm{PM}_{4}, \mathrm{P} 1$ & 0.71 & 0.23 & 75.06 \\
\hline TSP, P1 & 0.64 & 0.17 & 58.00 \\
\hline $\mathrm{PM}_{4}, \mathrm{P} 2$ & 0.82 & 0.66 & 4.23 \\
\hline TSP, P2 & 0.82 & 0.14 & 1.94 \\
\hline $\mathrm{PM}_{4}, \mathrm{P} 3$ & 0.55 & 0.49 & 252.65 \\
\hline TSP, P3 & 0.77 & 0.44 & 36.72 \\
\hline $\mathrm{PM}_{4}, \mathrm{P} 4$ & 0.78 & 0.57 & 25.97 \\
\hline TSP, P4 & 0.79 & 0.62 & 3.31 \\
\hline $\mathrm{PM}_{4}, \mathrm{P} 5$ & 0.76 & 0.44 & 33.69 \\
\hline TSP, P5 & 0.78 & 0.52 & 55.84 \\
\hline $\mathrm{PM}_{4}, \mathrm{P} 6$ & 0.81 & 0.68 & 3.41 \\
\hline TSP, P6 & 0.80 & 0.62 & 3.78 \\
\hline
\end{tabular}

Practically, there was no dependence between the dust concentrations and the $\sum \mathrm{PAH}$ concentrations (linear correlation coefficient was $\mathrm{R}^{2}=0.52$ ). Neither were the concentrations of particular PAHs correlated linearly with the dust concentrations $\left(\mathrm{R}^{2}<0.35\right)$. Such correlations would occur if the dust and its PAH content were of common provenance.

The PAH profiles at different points differed (Table 1). However, among the 16 PAHs, at almost each sampling point, Ch, Flt, BaA, BkF, and Pyr, the PAHs typical of the emissions from hard coal combustion or coking [19-21], had the highest concentrations. Additionally, the profile of $\mathrm{PM}_{4}$-bound PAHs was similar to the profile of TSP-bound PAHs at each point, and at P3 and P4 in the open air very similar, making common origin of the $\mathrm{PM}_{4}$ - and the TSPbound PAHs highly probable.

Usually, fine and coarse particles come from different sources and their PAH contents (PAH profiles) entirely differ $[19,20,22]$. The similarity of the profiles would not be surprising if the $\mathrm{PM}_{4}$ mass shares in TSP were very high, but in the sawmill they were not, except for PM at P1.

The residual doubts were removed by computing the values of diagnostic ratios (proportions of particular PAH concentrations [8, 20, 22-26]), which matched the values of such ratios for PAHs from coal combustion and coking (Table 2).

The three ratios assumed values close to those for PAHs from coking and coal combustion. The Flt/(Flt+Pyr) were slightly higher than those for coking (Table 2), so besides coal combustion and coking the combustion of wood in ovens (neighboring houses and allotment gardens) might be a source of PAHs in the sawmill [27]. Within the sawmill itself, there were no PAH sources - neither wood nor fossil fuels were burnt, and all the tools in use were electric. Wood burning caused by the process of sawing (dull or 
Table 3. Concentrations of $\sum \mathrm{PAH}$ and $\mathrm{BaP}$ and the values of the indicators of the exposure to the PAH mixture (CEQ, MEQ, TEQ, and $\left.\sum \mathrm{PAH}_{\text {carc }} / \sum \mathrm{PAH}\right)$ for $\mathrm{PM}_{4}$ - and TSP-bound PAHs at the sampling points in the sawmill (present study) and selected locations in Upper Silesia (literature).

\begin{tabular}{|c|c|c|c|c|c|}
\hline \multirow{2}{*}{$\begin{array}{c}\text { PM fraction, } \\
\text { location }\end{array}$} & $\mathrm{BaP}$ & $\mathrm{CEQ}^{\mathrm{a})}$ & $\mathrm{MEQ}^{\mathrm{b})}$ & \multirow{2}{*}{$\begin{array}{c}\left.\mathrm{TEQ}^{\mathrm{c}}\right) \\
\mathrm{pg} \cdot \mathrm{m}^{-3}\end{array}$} & \multirow{2}{*}{$\sum \mathrm{PAH}_{\text {carc }} \sum \mathrm{PAH}^{\mathrm{d})}$} \\
\hline & \multicolumn{3}{|c|}{$\mathrm{ng} \cdot \mathrm{m}^{-3}$} & & \\
\hline $\mathrm{PM}_{4}, \mathrm{P} 1$ & 9.97 & 14.38 & 15.48 & 116.06 & 0.42 \\
\hline TSP, P1 & 32.23 & 55.01 & 61.39 & 293.66 & 0.46 \\
\hline $\mathrm{PM}_{4}, \mathrm{P} 2$ & 16.41 & 23.79 & 30.75 & 145.32 & 0.47 \\
\hline TSP, P2 & 29.01 & 41.55 & 40.87 & 193.16 & 0.14 \\
\hline $\mathrm{PM}_{4}, \mathrm{P} 3$ & 25.56 & 86.79 & 39.72 & 166.60 & 0.40 \\
\hline TSP, P3 & 33.31 & 102.76 & 49.03 & 206.50 & 0.26 \\
\hline $\mathrm{PM}_{4}, \mathrm{P} 4$ & 11.01 & 14.07 & 15.53 & 53.36 & 0.22 \\
\hline TSP, P4 & 18.41 & 56.27 & 32.23 & 138.07 & 0.36 \\
\hline $\mathrm{PM}_{4}, \mathrm{P} 5$ & 4.45 & 6.59 & 6.53 & 53.47 & 0.33 \\
\hline TSP, P5 & 26.92 & 114.98 & 44.26 & 160.48 & 0.35 \\
\hline $\mathrm{PM}_{4}, \mathrm{P} 6$ & 13.05 & 68.91 & 25.08 & 171.01 & 0.33 \\
\hline TSP, P6 & 22.72 & 86.28 & 39.69 & 183.84 & 0.28 \\
\hline Złoty Potok, winter, regional background [15] & 4.03 & 5.85 & 4.87 & 7.36 & 0.52 \\
\hline Katowice, winter, urban background [15] & 12.48 & 18.46 & 20.47 & 91.95 & 0.56 \\
\hline Katowice, winter, highway [15] & 14.27 & 106 & 29.54 & 147.79 & 0.63 \\
\hline Złoty Potok, summer, regional background [15] & 2.46 & 4.50 & 4.29 & 13.8 & 0.5 \\
\hline Katowice, summer, urban background [15] & 2.97 & 5.29 & 4.23 & 13.71 & 0.59 \\
\hline Katowice, summer, highway [15] & 4.73 & 15.46 & 6.45 & 20.42 & 0.55 \\
\hline Zabrze, summer, crossroads [16] & 1.1 & 1.48 & 1.9 & 10.29 & 0.48 \\
\hline Ruda Śląska, summer, road [16] & 0.3 & 1.57 & 0.87 & 6.62 & 0.84 \\
\hline Zabrze, winter, urban background [18] & 16.09 & 25.04 & 25.24 & 116.03 & 0.66 \\
\hline
\end{tabular}

a) carcinogenic equivalent $\mathrm{CEQ}=0.001 \times[\mathrm{Na}]+[\mathrm{Acln}]+[\mathrm{Acn}]+[\mathrm{Flu}]+[\mathrm{Phen}]+[\mathrm{Flt}]+[\mathrm{Pyr}])+0.01 \times([\mathrm{An}]+[\mathrm{Ch}]+[\mathrm{BghiP}])+0.1 \times([\mathrm{BaA}]+[\mathrm{BbF}]+$ $+[\mathrm{BkF}]+[\mathrm{IP}])+1 \times[\mathrm{BaP}]+5 \times[\mathrm{DahA}]$; values of $0.001,0.01,0.1$, and 1 are the so-called toxic equivalence factors (TEF) for specific PAHs, taken from the [30];

b) mutagenic equivalent $\mathrm{MEQ}=0.00056 \times[\mathrm{Acnl}]+0.082 \times[\mathrm{BaA}]+0.017 \times[\mathrm{Ch}]+0.25 \times[\mathrm{BbF}]+0.11 \times[\mathrm{BkF}]+1 \times[\mathrm{BaP}]+0.31 \times[\mathrm{IP}]+0.29 \times[\mathrm{DahA}]$ $+0.19 \times[$ BghiP]; values of $0.00056,0.082,0.017,0.25,0.11,1,0.31,0.29,0.19$, and 0.01 are the so-called minimum mutagenic concentrations (MMC) for specific PAHs, taken from the study [31];

c) TCDD-toxic equivalent TEQ $=0.000025 \times[\mathrm{BaA}]+0.00020 \times[\mathrm{Ch}]+0.000354 \times[\mathrm{BaP}]+0.00110 \times[\mathrm{IP}]+0.00203 \times[\mathrm{DahA}]+0.00253 \times[\mathrm{BbF}]+$ $+0.00487 \times[\mathrm{BkF}]$; values of $0.000025,0.00020,0.000354,0.00110,0.00203,0.00253$, and 0.00487 are the so-called. TCDD-TEF, i.e., toxic equivalency factor relative to 2,3,7,8-tetrachlorodibenzo-p-dioxin TCDD (for TCDD, TEF $=1.0$ ) for specific PAHs, taken from the study [32];

d) the share of the carcinogenic PAHs $\left(\sum \mathrm{PAH}_{\text {carc }}\right.$; [33]) in $\left(\sum \mathrm{PAH}\right) \sum \mathrm{PAH}_{\mathrm{carc}} / \sum \mathrm{PAH}=([\mathrm{BaA}]+[\mathrm{BaP}]+[\mathrm{BbF}]+[\mathrm{BkF}]+[\mathrm{Ch}]+[\mathrm{DahA}]+$ $+[\mathrm{IP}]) /([\mathrm{Acnl}]+[\mathrm{Acn}]+[\mathrm{Flu}]+[\mathrm{Phen}]+[\mathrm{An}]+[\mathrm{Flt}]+[\mathrm{Pyr}]+[\mathrm{BaA}]+[\mathrm{Ch}]+[\mathrm{BbF}]+[\mathrm{BkF}]+[\mathrm{BaP}]+[\mathrm{DahA}]+[\mathrm{BghiP}]+[\mathrm{IP}])$.

dirty blade, warped blade, etc.) was not observed in the sampling period. Usually, even if such malfunction occurs, it is handled rather instantly and cannot be considered a significant source of PAHs.

Because there were no PAH sources within the sawmill, municipal emissions (from heating) were negligible because the sampling period was rather hot, and one of the biggest Silesian cokeries was about $200 \mathrm{~m}$ north of the sawmill, the hard coal coking was assumed to account for such enormously high PM-bound PAH concentrations in the sawmill. The high indoor PAH concentrations can be accounted for by PAH absorption and accumulation in sawdust, a very efficient sorbent of gaseous substances [28, 29]. Elsewhere in Zabrze, in the open air, they are lower [18, 25 , probably because they naturally propagate in the atmosphere [20]. Accordingly, at the outdoor P4 (at the sawmill gate) they were the lowest among the PAH concentrations in the sawmill. 
Therefore, the sawmill workers are exposed to hazard from high indoor PAH concentrations. The CEQ for the $\mathrm{PM}_{4}$-bound 16 PAH mixture was from 6.59 to $86.79 \mathrm{ng} \cdot \mathrm{m}^{-3}$, and for the TSP-bound from 41.55 to $114.98 \mathrm{ng} \cdot \mathrm{m}^{-3}$, depending on the sampling point. They were high, elsewhere in Silesia they are much lower (Table 3). Such high values of CEQ were noted only at a highway in Katowice, the capital of Silesia, in winter. The MEQ and TEQ in the sawmill were also high, such that their values were noted in Silesian cities (Zabrze, Katowice) only in winter (Table 3). However, the share of $\sum \mathrm{PAH}_{\text {carc }}$ in $\sum \mathrm{PAH}$ (i.e. $\left.\sum \mathrm{PAH}_{\text {carc }} \sum \mathrm{PAH}\right)$ was not higher than $47 \%$ at any point;in other regions of Silesia it happens to be higher.

This resemblance of the mixture PAH hazard coefficients in the sawmill to the coefficients in big cities in winter ensures that the PAHs in the sawmill came from a hightemperature processing of hard coal (combustion or/and coking).

\section{Conclusions}

The pilot research shows that the concentrations of $\mathrm{PM}_{4}$ and TSP within the sawmill are not so high as to be hazardous. The mass shares of potentially hazardous $\mathrm{PM}_{4}$ in TSP at the main saw and other wood processing equipment were higher than elsewhere in the sawmill, but the differences were not great.

The real hazard to the indoor workers came from the PM-bound PAHs. The indoor concentrations of PM-bound $\sum \mathrm{PAH}$ in the sawmill were very high. The PAH profiles at the sampling sites and the values of the diagnostic ratios suggest that the PAHs came from hard coal coking or combustion (of coal or wood). Because there is no such PAH source within the sawmill, the PAHs were assumed to come from the nearby coking plant. Less than half of the $16 \mathrm{PAHs}$ were heavier $\mathrm{BaA}, \mathrm{BaP}, \mathrm{BbF}, \mathrm{BkF}, \mathrm{Ch}$, DahA, or IP (carcinogens); this and the PAH profiles suggest that the majority of the mass of PAHs to be found in the sawmill were light gaseous PAHs adsorbed on the developed surface of sawdust particles. The intense PAH emissions from the cokery and the high adsorption capacity of the sawdust combine to cumulate PAH in amounts sufficient to cause indoor PAH concentrations in the sawmill comparable to PAH concentrations along a highway in winter.

\section{Acknowledgements}

This work was realized within the DEC2013/09/N/ST10/04224 project, financed by the National Science Centre. The sampling was partially performed within the Eko-Staż project financed by the Regional Chamber of Commerce in Katowice, the University of Silesia in Katowice, the Polish Federation of Engineering Associations NOT, the City Council of Gliwice, and by the EU from the European Social Fund (residency program realized by W. Rogula-Kozłowska and B. Kozielska).

\section{References}

1. PASTUSZKA J., HŁAWICZKA S., WILlEKE K. Particulate pollution levels in Katowice, a highly industrialized Polish city. Atmos. Environ. 27B, (1), 59, 1993.

2. HŁAWICZKA S., DYDUCH B., FUDALA J. Long-term changes of particulate emission in the industrial region of upper Silesia (Poland) and their effect on the acidity of rainwater. Water Air Soil Pollut. 142, (1-4), 151, 2003.

3. CSO: Central Statistical Office, Statistical Yearbook Śląskie Voivodship http://katowice.stat.gov.pl/rocznik-statystycznywojewodztwa-slaskiego-2013-873, 2013.

4. JONES A.P. Indoor air quality and health. Atmos. Environ. 33, (28), 4535, 1999.

5. MONN C. Exposure assessment of air pollutants: A review on spatial heterogeneity and indoor/outdoor/personal exposure to suspended particulate matter, nitrogen dioxide and ozone. Atmos. Environ. 35, (1), 1, 2001.

6. SHEESLEY R.J., SCHAUER J.J., SMITH T.J., GARSHICK E., LADEN F., MARR L.C., MOLINA L.T. Assessment of diesel particulate matter exposure in the workplace: Freight terminals. J. Environ. Monit. 10, (3), 305, 2008.

7. ŞAHIN U.A., KURUTAŞ B. Assessment of fine particulate matter and gaseous pollutants in workplace atmosphere of metallic industry. Bull. Environ. Contam. Tox. 89, (4), 898, 2012.

8. KOZIELSKA B., KONIECZYŃSKI J. Polycyclic aromatic hydrocarbons in particulate matter emitted from coke oven battery. Fuel 144, 327, 2015.

9. DE CARVALHO A.B., KATO M., REZENDE M.M., DE P. PEREIRA P.A., DE ANDRADE J.B. Exposure to carbonyl compounds in charcoal production plants in Bahia, Brazil. Environ. Sci. Pollut. Res. 20, (3), 1565, 2013.

10. BADYDA A.J., DĄBROWIECKI P., LUBIŃSKI W., CZECHOWSKI P.O., MAJEWSKI G. Exposure to trafficrelated air pollutants as a risk of airway obstruction. Adv. Exp. Med. Biol. 755, 35, 2013.

11. LAU W.K.Y., LIANG P., MAN Y.B., CHUNG S.S., WONG M.H. Human health risk assessment based on trace metals in suspended air particulates, surface dust, and floor dust from e-waste recycling workshops in Hong Kong, China. Environ. Sci. Pollut. Res. 21, (5), 3813, 2014.

12. J.Law. 2014 Item. 817; Ordinance of the Minister of Labour and Social Policy of 6 June 2014 on maximum permissible concentration and intensity of harmful factors in the workplace [In Polish].

13. PN-91/Z-04030/05 Air purity protection. Research dust content. Determination of total dust on workstations with filtration-weight [In Polish].

14. PN-91/Z-04030/06 Air purity protection. Research dust content. Determination of respirable dust on workstations with filtration-weight [In Polish].

15. ROGULA-KOZŁOWSKA W., KOZIELSKA B., KLEJNOWSKI K. Concentration, origin and health hazard from fine particle-bound PAH at three characteristic sites in southern Poland. B. Environ. Contam. Tox. 91, (3), 349, 2013.

16. KOZIELSKA B., ROGULA-KOZŁOWSKA W., PASTUSZKA J.S. Traffic emission effects on ambient air pollution by PM2.5-related PAH in Upper Silesia, Poland. Int. J. Environ. Pollut. 53, (3-4), 245, 2013.

17. ROGULA-KOZŁOWSKA W., KLEJNOWSKI K., ROGULA-KOPIEC P., MATHEWS B., SZOPA S. A study on the seasonal mass closure of ambient fine and coarse dusts in Zabrze, Poland. B. Environ. Contam. Tox. 88, (5), 722, 2012. 
18. ROGULA-KOZŁOWSKA W., KOZIELSKA B., KLEJNOWSKI K., SZOPA S. Hazardous compounds in urban PM in the central part of Upper Silesia (Poland) in winter. Arch. Environ. Prot. 39, (1), 53, 2013.

19. HARRISON R.M., SMITH D.J.T., LUHANA L. Source apportionment of atmospheric polycyclic aromatic hydrocarbons collected from an urban location in Birmingham. UK. Environ. Sci. Technol. 30, (3), 825, 1996.

20. RAVINDRA K., SOKHI R., VAN GRIEKEN R. Atmospheric polycyclic aromatic hydrocarbons: Source attribution, emission factors and regulation. Atmos. Environ. 42, (13), 2895, 2008.

21. FABIAŃSKA M.J., ĆMIEL S.R., MISZ-KENNAN M. Biomarkers and aromatic hydrocarbons in bituminous coals of Upper Silesian Coal Basin: Example from 405 coal seam of the Zaleskie Beds (Poland). Int. J. Coal Geol. 107, (3), 96, 2013.

22. SAARNIO K., SILLANPAÄ M., HILLAMO R., SANDELL E., PENNANEN A.S., SALONEN R.O. Polycyclic aromatic hydrocarbons in size-segregated particulate matter from six urban sites in Europe. Atmos. Environ. 42, (40), 9087, 2008.

23. TANG N., HATTORI T., TAGA R., IGARASHI K., YANG X., TAMURA K., KAKIMOTO H., MISHUKOV V.F., TORIBA A., KIZU R., HAYAKAWA K. Polycyclic aromatic hydrocarbons and nitropolycyclic aromatic hydrocarbons in urban air particulates and their relationship to emission sources in the Pan-Japan Sea countries. Atmos. Environ. 39, (32), 5817, 2005.

24. KONG S., DING X., BAI Z., HAN B., CHEN L., SHI J., LI $Z$. A seasonal study of polycyclic aromatic hydrocarbons in PM2.5 and PM2.5-10 in five typical cities of Liaoning Province, China. J. Hazard. Mater. 183, (1-3), 70, 2010.

25. ROGULA-KOZLOWSKA W., KOZIELSKA B., BŁASZCZAK B., KLEJNOWSKI K. The mass distribution of particle-bound PAH among aerosol fractions: A case- study of an urban area in Poland, Organic Pollutants Ten Years after the Stockholm Convention - Environmental and Analytical Update, InTech, 163, 2012.

26. TOBISZEWSKI M., NAMIEŚNIK J. PAH diagnostic ratios for the identification of pollution emission sources. Environ. Pollut. 16, 110, 2012.

27. DELGADO-SABORIT J.M., STARK C., HARRISON R.M. Carcinogenic potential, levels and sources of polycyclic aromatic hydrocarbon mixtures in indoor and outdoor environments and their implications for air quality standards. Environ. Int. 37, (2), 383, 2011.

28. INAGAKI M., KAWAHARA A., KONNO H. Sorption and recovery of heavy oils using carbonized fir fibers and recycling. Carbon 40, (1), 105, 2002.

29. JANOŠ P., COSKUN S., PILAŘOVÁ V., REJNEK J. Removal of basic (Methylene Blue) and acid (Egacid Orange) dyes from waters by sorption on chemically treated wood shavings. Bioresour. Technol. 100, (3), 1450, 2009.

30. NISBET I.C.T., LAGOY P.K. Toxic Equivalency Factors (TEFs) for Polycyclic Aromatic Hydrocarbons (PAHs), Regul. Toxicol. Pharm. 16, (1), 290, 1992.

31. DURANT J.L., BUSBY JR. W.F., LAFLEUR A.L., PENMAN B.W., CRESPI C.L. Human cell mutagenicity of oxygenated, nitrated and unsubstituted polycyclic aromatic hydrocarbons associated with urban aerosols. Mutat. Res.Genet. Tox. 371, (3-4), 123, 1996.

32. WILLETT K.L., GARDINALI P.R., SERICANO J.L., WADE T.L., SAFE S.H. Characterization of the H4IIE rat hepatoma cell bioassay for evaluation of environmental samples containing Polynuclear Aromatic Hydrocarbons (PAHs). Arch. Environ. Con. Tox. 32, (4), 442, 1997.

33. USEPA: ENVIRONMENTAL PROTECTION AGENCY. Polycyclic Aromatic Hydrocarbons (PAHs) - EPA Fact Sheet; National Center for Environmental Assessment, Office of Research and Development: Washington, DC, USA, 2008. 
